\title{
ISOLATION AND PHYSICO-CHEMICAL CHARACTERIZATION OF COLA STARCH
}

\section{O mojola $\mathrm{MO}^{1^{*}}, \mathrm{Akinkunmi} \mathrm{YO}^{2}$, Olufunsho $\mathrm{KO}^{3}$,} Egharevba $\mathrm{HO}^{3}$ and $\mathrm{EO} \mathrm{M}_{\text {artins }}^{3}$

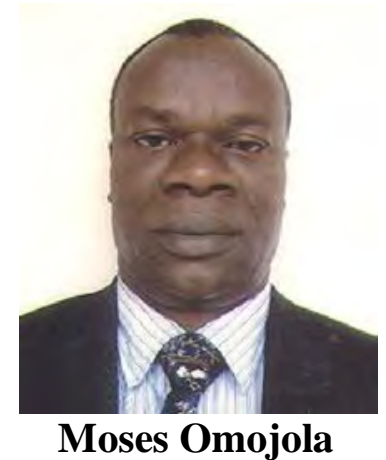

*Corresponding author email: omojolamoses@ @otmail.com

${ }^{1}$ *Corresponding author: Raw Materials Research and Development Council PMB 232 Garki, Abuja. Nigeria.

${ }^{2}$ National Office for Technology Acquisition and Promotion, PMB 5074, Wuse Abuja.

${ }^{3}$ National Institute for Pharmaceutical and Development (NIPRD), PMB 21 Garki, Abuja Nigeria. 


\section{ABSTRACT}

Cola nitida (Vent).Schott \& Endl, a tropical dicotyledonous tree (family- malvaceae and sub-family - stercullioideae), is a well known plant in the sub-Saharan Africa and renowned for its socio-economic importance in Nigeria and other parts of West Africa. The plant was examined for the nut's starch composition and its physicochemical properties compared with corn starch. The starch was isolated using $1 \% \mathrm{w} / \mathrm{v}$ sodium metabisulphite and the proximate analysis (in \%) was found to be 4.60 protein, 0.54 crude fibre, 0.54 fat, 1.06 ash, 67.57 total starch and 10.42 moisture. The starch percentage solubility was $7.48 \%$ with a swelling capacity of $8.85 \%$ and an amylose/amylopectin content of 24:76. It has a pasting temperature of $74.5^{\circ} \mathrm{C}$, gelatinization temperature of $74{ }^{\circ} \mathrm{C}$ hydration capacity of $88.59 \%$, emulsion and foam capacities of $5.22 \%$ and $1.87 \%$ respectively. The Rapid Visco Analysis (RVA) of the cola starch has a peak viscosity of 314.42 RVU and the results of the Differential Scanning Calorimetry (DSC) showed peak temperature of $321{ }^{\circ} \mathrm{C}$ and onset temperature of $300.7^{\circ} \mathrm{C}$. The photomicrograph indicates that the starch granule is oval in shape, generally small sized with occasional large ones, loose granules with no aggregation and had a mean particle size distribution of $15.33 \%$ at $710 \mu \mathrm{m}$. The mineral content composition gave: iron $0.263 \mathrm{mg} / 100 \mathrm{~g}$; phosphorus $67.43 \mathrm{mg} / 100 \mathrm{~g}$; potassium $4.36 \mathrm{mg} / 100 \mathrm{~g}$; calcium $9.40 \mathrm{mg} / 100 \mathrm{~g}$; zinc $0.48 \mathrm{mg} / 100 \mathrm{~g}$; magnesium $3.78 \mathrm{mg} / 100 \mathrm{~g}$; copper (trace), and sodium $1.55 \mathrm{mg} / 100 \mathrm{~g}$. Generally, the values obtained for the physicochemical and functional properties compared favorably with that of corn starch, and suggest that cola starch in the unmodified form can be used as a gelling agent, a fat replacer in the food industries where low fat is required and in the manufacture of noodles. It however cannot be used as an emulsifier as a result of its low emulsion and foam capacities.

K ey words: Cola, starch, isolation, composition, properties 


\section{INTRODUCTION}

Starch is one of the most widely used biomaterials in the food, textile, cosmetics, and plastic, adhesives, paper and pharmaceutical industries. The diverse industrial usage of the materials is premised on its availability at low cost, high caloric value, inherent excellent physicochemical properties and the ease of its modification to other derivatives. The versatility of starch in industrial applications is clearly defined by its physicochemical properties; therefore a thorough evaluation of the necessary parameters is important in elucidating its industrial use. The morphology and physicochemical characteristics of starch are typical of its biological origin; hence starch from each plant source will vary somewhat in appearance, composition and properties [1]. The search for starch with excellent properties from conventional and non-conventional sources will therefore continue to excite scientists and technologist, as genetic background and the environment have been found to be responsible for changes in morphology and composition of corn starch during plant development [2], which is also applicable to other starches.

Many tropical countries have plant species which can be used as a good source of starch for various purposes; unfortunately some of them have not been fully investigated. One such plant species is kolanut- C. nitida rubra. It is a tropical dicotyledonous tree which belongs to the family of Malvaceae. The crop is socioeconomically important because it is used in many parts of Nigeria for prayers and blessings during child naming, elders meeting, house warming, etc and commonly chewed as a masticant and stimulant. It is also a good source of caffeine which is used in pharmaceutical industries. In the developed countries, the kolanut extract find its use industrially in the manufacture of many cola-type soft drinks flavours, where it appears to be more effective than other flavours. Previous investigations have mentioned the various uses of $\mathrm{C}$. nitida and other related nuts in wine and soft drink production $[3,4]$, but its industrial potential has not been fully explored in the food \& pharmaceutical industries.

The aim of this research is to isolate the starch in C. nitida, characterize and provide information on its composition, morphology and some selected physicochemical properties that may provide an insight into its usefulness in the pharmaceutical, cosmetic, and food industries, using corn starch BP (British Pharmacopoeia) as a comparing standard.

\section{MATERIALSAND METHODS}

\section{M aterials}

C.nitida were procured directly from the farm source in Ondo, Ondo state. Nigeria. The nuts were removed from the pods, wrapped in green leaves and kept in a basket at room temperature until required. This is necessary to ensure the retention of the quality of the nuts. Sodium metabisulphite (- BDH, UK) was purchased from Zion Chemicals, Abuja. Corn starch (BP) and Analytical Grade chemicals were obtained 
from the Pharm Tech Dept, National Institute for Pharmaceutical Research and Development. Idu, Abuja Nigeria.

\section{Starch I solation}

The method of extraction of starch from Tigernut Cyperus was adopted with little modification [5]. Clean nuts $(3 \mathrm{~kg})$ washed in water, were crushed and soaked for $1 \mathrm{~h}$ in sodium metabisulphite solution $(2 \mathrm{~L} 1 \% \mathrm{w} / \mathrm{v})$ at room temperature $\left(28{ }^{\circ} \mathrm{C}\right)$. Thereafter, the nuts were removed and wet milled into a homogenous fine paste using domestic blender. The paste was dispersed in a large volume of $1 \%$ sodium metabisulphite, and filtered through muslin cloth. The suspension was allowed to settle and the supernatant was decanted. The sediment starch layer was re-suspended in sodium metabisulphite solution and the process was repeated for four times. At each stage of washing, the suspension was allowed to stand for about $90 \mathrm{~min}$ for proper sedimentation after which the supernatant was decanted. The mucilage on the starch was scraped continuously until a pure starch was obtained. The resulting starch was dried at $60{ }^{\circ} \mathrm{C}$ in a hot air oven, pulverized, weighed and stored in cellophane wrap for analysis.

Determination of chemical composition and physicochemical properties

A $20 \% \mathrm{w} / \mathrm{v}$ dispersion of the samples was shaken in water for $5 \mathrm{~min}$, and the $\mathrm{pH}$ was determined using a $\mathrm{pH}$ meter (Corning, UK).

Moisture, protein, fat, ash and mineral contents were determined by AOAC methods [6].

The swelling and solubility capacities were determined over a temperature range of 0 $100{ }^{\circ} \mathrm{C}$ as follows: $1 \mathrm{~g}$ each of cola and corn starches were poured separately into calibrated boiling tubes of known weight and the initial volume was recorded. $10 \mathrm{ml}$ of distilled water was added and it was subjected to a vortex mixer (Vortex-2Genie, set at shake 8) for $5 \mathrm{~min}$ and allowed to settle. The tubes were immersed in thermostated water, with a starting temperature of $50{ }^{\circ} \mathrm{C}$, and heated for $30 \mathrm{~min}$ after which the tubes were centrifuged at $3000 \mathrm{rpm}$ for $10 \mathrm{~min}$. The supernatant was decanted into petri dishes of known weight and dried in an oven. The difference in weight was calculated as the $\%$ solubility index. Also, the weight of the sediment was determined and used to calculate the $\%$ swelling capacity. This was carried out for every $5{ }^{\circ} \mathrm{C}$ rise in temperature at $30 \mathrm{~min}$ interval till $95^{\circ} \mathrm{C}$ [7].

Amylose content determination was carried out using a colorimetric iodine affinity procedure [8]. The starch samples $(0.1 \mathrm{~g})$ each standard were weighted into separate test tubes. To each test tube was added carefully $1 \mathrm{ml}$ of $95 \%$ ethanol and $9 \mathrm{ml} 1 \mathrm{~mol}$ $\mathrm{dm}^{-3} \mathrm{NaOH}$. The tubes were covered with foil, thoroughly mixed and heated for 10 min in boiling water both to gelatinize the starch, thereafter it was cooled very well. The suspensions were diluted 10 times. An aliquot of $0.5 \mathrm{ml}$ of the extract was used for analysis where $0.1 \mathrm{ml}$ of acetic acid solution was added, followed by the addition of $0.2 \mathrm{ml}$ of iodine solution. This was made up to $10 \mathrm{ml}$ mark with distilled water. The solution was left for 20 min for colour development, and absorbance was read at $620 \mathrm{~nm}$.

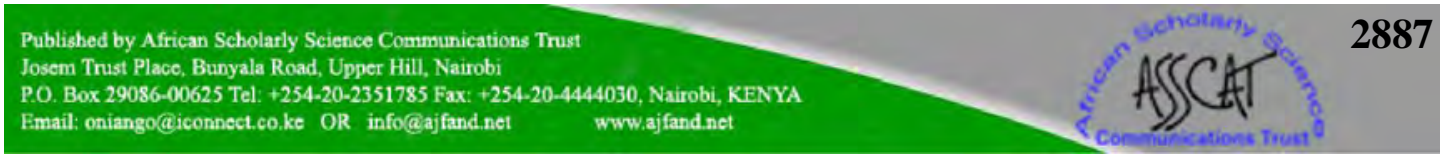


Foam and emulsion capacities were determined by method as described by Onwuka [9]. The cola and corn starches ( $2 \mathrm{~g}$ each) were separately homogenized in $100 \mathrm{ml}$ of distilled water using a vortex mixer (Vortex 2 Genie set at shake 8 ) for $5 \mathrm{~min}$. The homogenate was poured into a $250 \mathrm{ml}$ measuring cylinder and the volume recorded after $30 \mathrm{~s}$. The foam capacity was expressed as the percent increase in volume. For the emulsion capacity, $2 \mathrm{~g}$ of cola and corn starches respectively were dispensed in 25 $\mathrm{ml}$ of distilled water, using a vortex mixer for $30 \mathrm{~s}$. After complete dispersion, $25 \mathrm{ml}$ of vegetable oil (ground nut oil), was added gradually and the mixing continued for another $30 \mathrm{~s}$. The suspension was centrifuged at $1600 \mathrm{rpm}$ for $5 \mathrm{~min}$. The volume of oil separated from the sample was read directly from the tube. Emulsion capacity is the amount of oil emulsified and held per gram of sample.

Water absorption capacity was determined as follows; $80 \% \mathrm{w} / \mathrm{v}$ of both cola and corn starches were dispersed in a pre-weighed centrifuge tubes. The tubes were agitated in a vortex mixer for $2 \mathrm{~min}$ and centrifuged at $400 \mathrm{rpm}$ for $20 \mathrm{~min}$. The supernatant was discarded and the weight of the tube and hydrated sample taken. The weight was calculated and expressed as the weight of water bound by $100 \mathrm{~g}$ dry starches [10].

All the above parameters were determined in triplicate and the mean and standard deviations were recorded. A light microscope with a micrometer (Nikon AFX 35DX microscope, Japan) connected to a computer was used to determine the particle sizes at $40 \mathrm{x}$ magnification and the photomicrograph recorded. The pasting temperature and viscosity of $12 \% \mathrm{w} / \mathrm{v}$ of both cola and corn starches were readily assessed using the Rapid Visco Analyser model RVA-3D made compatible with a computer. The samples were assessed for peak viscosity, trough, breakdown, and final viscosity, set back, peak time and pasting temperature. Gelatinization properties of the samples were characterized using a Netzsch DSC 204 F1 Phoenix (Netzsch, Germany). Nitrogen, at the rate of $20 \mathrm{ml} / \mathrm{min}$, was used as purge gas; $2.7 \mathrm{mg}$ of powdered material was sealed in an aluminum pan and heated from $30{ }^{\circ} \mathrm{C}$ up to 400 ${ }^{\circ} \mathrm{C}$ at the rate of $10^{\circ} \mathrm{C} / \mathrm{min}$, followed by a cooling cycle back to $30^{\circ} \mathrm{C}$ at the same rate. The onset gelatinization temperature $\left(\mathrm{T}_{\mathrm{o}}\right)$, peak temperature $\left(\mathrm{T}_{\mathrm{p}}\right)$, and gelatinization temperature at end $\left(\mathrm{T}_{\mathrm{e}}\right)$, were recorded.

\section{RESULTS}

Table 1 shows the particle size distribution of cola and corn starches and their photomicrographs are depicted in Plates $1 \& 2$ (Figures $3 \& 4$ ). The physicochemical and functional properties of both starches are given in Table 2. The correlation coefficient $(\mathrm{r})$ between the mean values is 0.905 . The pasting properties and DSC thermo grams of the cola and corn starches are given in Tables 3 and 4 respectively. The solubility and swelling patterns for both starches are given in Figures 1 and 2. 


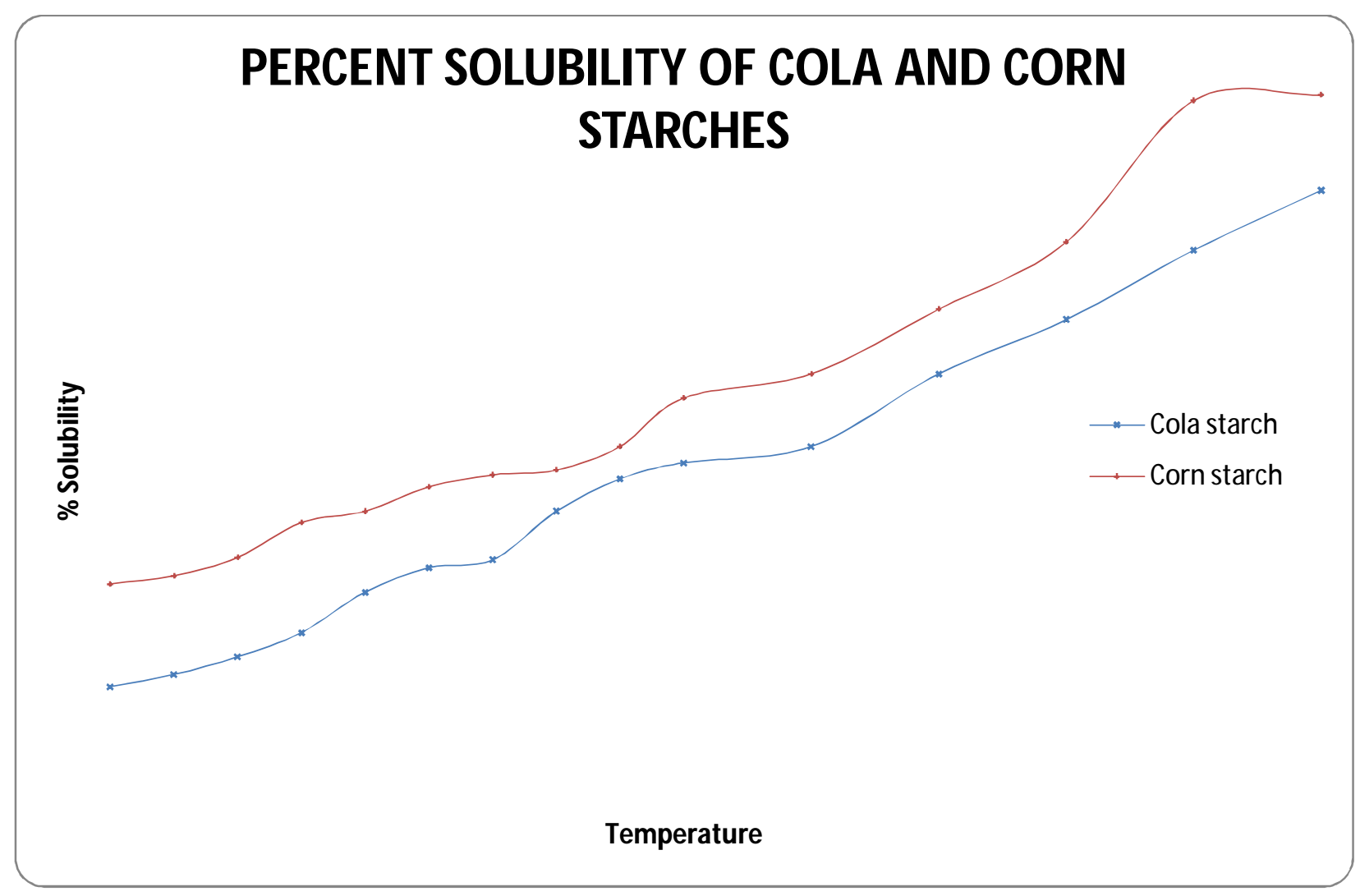

Figure 1: Solubility Curves for Cola and corn Starches 


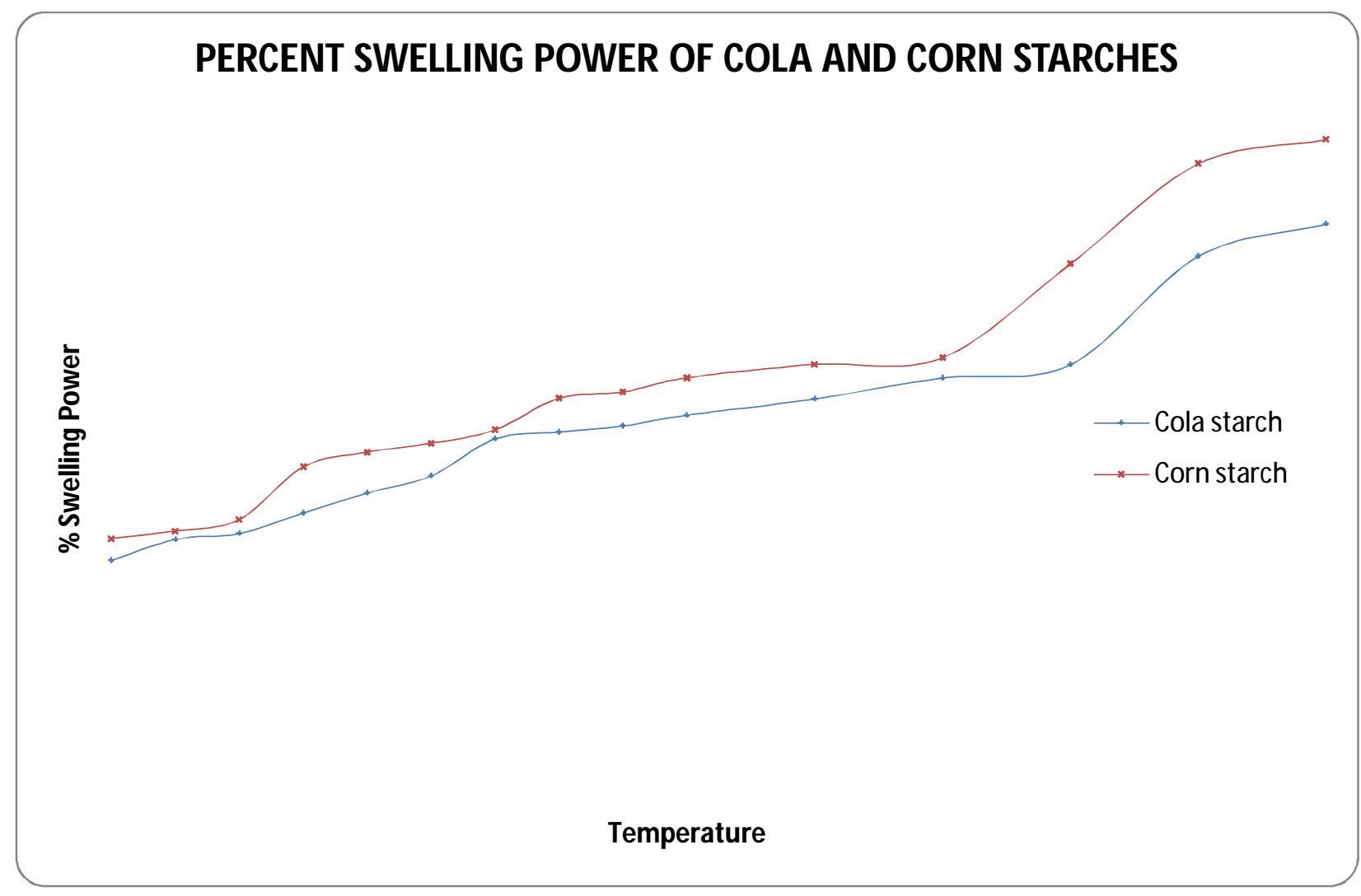

Figure 2: Swelling powers of Cola and corn Starches

\section{DISCUSSION}

The starch obtained was white, tasteless with no smell and the yield was about $20 \%$ wt/wt, with a purity of about $70 \%$. The yield is considered to be appreciable especially when compared with starches from other sources. Based on the yield and purity, cola starch can be regarded as a commercial product. The $\mathrm{pH}$ of 5.5 for the cola starch is the same as that of corn starch, and within the $\mathrm{pH}$ range of 3-9 obtained for most starches used in the pharmaceutical, cosmetics, and food industries. Generally, the fat, protein, moisture, crude fibre, water soluble ash, acid insoluble ash, alkaline soluble ash, total ash, and the mineral contents of cola starch were slightly higher than corn starch, but are within the range of values obtained for other starches $[5,7,11]$. This is a reflection of the biological origin of the starch material and the methods of extraction $[3,7,12]$. Cola and corn plants are non-leguminous plants and are therefore expected to have minimal amounts of fat and protein. The higher moisture content of cola starch is a reflection of the loose granules of cola starch and confirms that the granules are not tightly associated together compared to corn starch.

The density results show that cola starch compares favourably with corn starch. The amylose content of 24 and $27 \%$ for cola and corn starches respectively shows a nonwaxy starch type as most native starches contain $20-30 \%$ by weight of amylose. 
These values are high when compared with other starches. Starches with high amylose content (as shown above) are frequently used in the manufacture of noodles [13] and they affect their pasting properties. The foam capacities for both starches are very low and the emulsion capacity of cola starch is extremely low when compared with other starches such as corn and parkia starches [14].This suggests that cola starch cannot be used as an emulsifier in the food industries. The water holding capacities of both starches are very high, but that of cola starch is slightly lower, this is possibly due to the higher amylose content in corn starch. These values are very high when compared with other starches such as potato, tapioca and D. nipponica Makino [15]. It has been reported that the degree of water absorption of a starch is directly related to its amylose content and starches with high amylose content generally have high water absorption capacities, which has been found to improve the capacity of starch granules to expand in volume without collapsing [14].

\section{M orphology}

It can be seen from Table 1 that the mean particle size distribution at $710 \mu \mathrm{m}$ is 15.3 $\%$ for cola starch and $10.2 \%$ for corn starch and both starches show normal particle size distribution. Cola starch granules are small-sized of uniform sizes with occasional large ones, oval in shape and with the walls that are generally smooth without edges. They occurred as a single form and showed absence of aggregation. Corn starch granules are also small-sized, mostly spherical with some occurring as polygon or in some cases spherical with edges. They show aggregation forming lumps. The variation in the particle sizes is as a result of the different genetic background and environment in which cola and corn plants grow. Generally, small and medium sized starch granules have been reported to have varied industrial utilization in the food and pharmaceutical industries. [16, 17], which gives credence to the industrial potentials of cola starch.

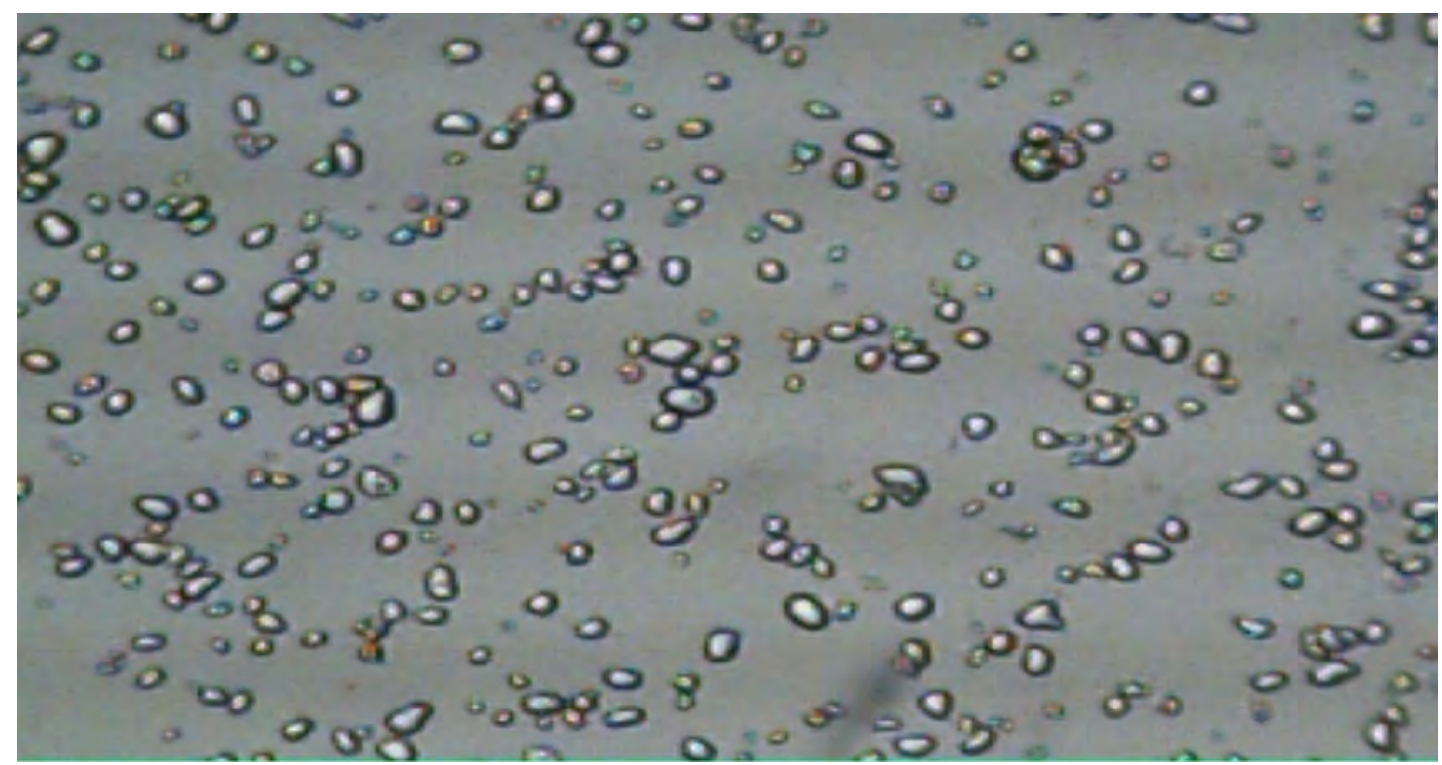

Figure 3: The photomicrograph of cola starch granule showing absence of aggregation (Plate 1) 

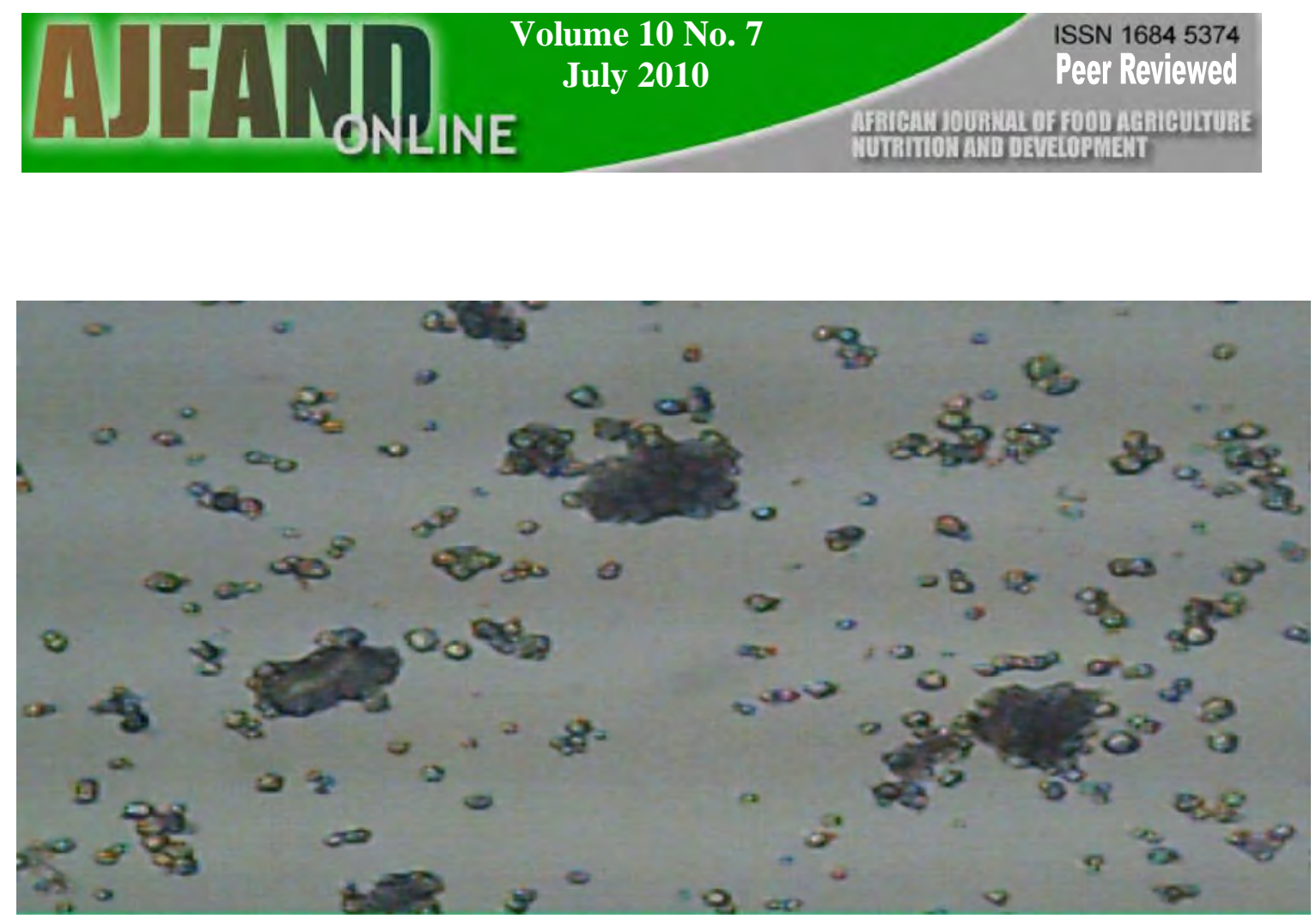

Figure 4: The photomicrograph of corn starch granule showing aggregation (Plate 2)

\section{Swelling and Solubility}

The solubility and swelling profiles of cola and corn starches over a temperature range of $50-100{ }^{\circ} \mathrm{C}$ are presented in Figures $1 \& 2$. The swelling behavior is an indication of the water absorption characteristics of the granules during heating. Generally, the solubility and swelling profiles show a general trend of increase with increase in temperature. Although, a slightly two-stage swelling patterns for both starches can be observed, first, a rapid increase up till around $60-70{ }^{\circ} \mathrm{C}$ followed by a slight level-off and another rapid increase around $80-90{ }^{\circ} \mathrm{C}$. This pattern has been attributed to two sets of internal bonding forces that relax at different temperatures [18]. Corn starch however shows a higher solubility and swelling capacities throughout the temperature range than cola starch. This indicates a greater degree of associative forces in the granules which reflects higher amylose content [19]. The swelling power exhibited by cola starch was lower than corn starch which also corresponds to its lower breakdown viscosity (Table 4). This may be due to the higher fat content and fats are known to inhibit swelling by forming insoluble complexes with the linear fraction of starch [1]. A lower swelling capacity of cola starch suggests a more stable granular structure and such starch can be utilized in food manufacture with minimal modification.

\section{Pasting Properties}

The pasting properties of both starches are given in Table 3. It can be seen that the two starches attained their peak viscosities of 314.4 and 571.9 (RVU) for cola and corn starches respectively at a peak time of $5 \mathrm{~min}$. The peak viscosity is an important distinguishing feature of every starch. The peak, trough, breakdown, final and set back viscosities (RVU) of cola starch is lower than that of corn starch which is still a reflection of the higher amylose and lower protein contents in corn starch. The higher 
breakdown viscosity in corn starch suggests that the sample had undergone a higher degree of swelling and subsequent disintegration $[15,20]$ and this is evident in the high swelling power of corn starch. The relatively high set back viscosity in both starches indicates their suitability in the manufacture of food products like noodles where greater retro gradation is required. The pasting temperature of the cola starch was observed to be $74.5^{\circ} \mathrm{C}$ which was lower than $80{ }^{\circ} \mathrm{C}$ recorded for corn starch. The pasting properties are known to be influenced by the degree and type of molecular association in the starch. The pasting temperature is one of the pasting properties which provide an indication of the minimum temperature required for sample cooking, energy costs involved and other components stability.

\section{Gelatinization Properties}

Starch granules are generally insoluble in cold water. They undergo a reversible reaction in cold water, swelling slightly and becoming hydrated. However, when heat is applied, the change becomes irreversible, and the granules swell more and gradually become a paste. This sequence of change from dispersion to paste is known as starch gelatinization [1]. The Differential Scanning Calorimetry (DSC) provides an accurate and reproducible method for monitoring the gelatinization process.

The data obtained for the DSC thermo grams for cola and corn starches are given in Table 4. It can be seen that the, onset temperature (To), peak temperature (Tp) and set temperature (Te) values for both starches are similar, and since, gelatinization temperatures reflect the degree of orderliness of the molecules in the granules, it therefore follows that both starches possess about the same structural rigidity.

Corn starch, although, has a higher gelatinization temperature $\left(80^{\circ} \mathrm{C}\right)$ than cola starch $\left(74{ }^{\circ} \mathrm{C}\right)$. This is probably due to its higher amylose content. High amylose content has been found to influence gelatinization temperature [14].The gelatinization temperature obtained for both starches are within the range of $60-95{ }^{\circ} \mathrm{C}$ commonly observed for starches.

\section{CONCLUSION}

Some of the physico-chemical properties of cola starch (cola nitida ) were examined. The starch granules are oval in shape, generally small sized with occasional large ones, loose granules with no aggregation. The average particle size of cola starch granule is slightly larger than corn starch. The amylose, water holding capacity, swelling and solubility patterns are slightly lower but comparable to corn starch. The results of the gelatinization and pasting properties suggest the presence of strong internal bonding forces within the granules of cola starch.

The study has, therefore, shown that C. nitida is a good source of starch, its physicochemical properties compare favourably with corn starch (BP), and it is therefore, a potential industrial starch especially for the food industries. 


\section{ACKNOWLEDGEMENT}

The authors wish to thank the Management of the National Institute for Pharmaceutical Research and Development, Abuja and The International Institute of Tropical Agriculture (IITA), Ibadan, Nigeria for the use of their laboratory facilities. 


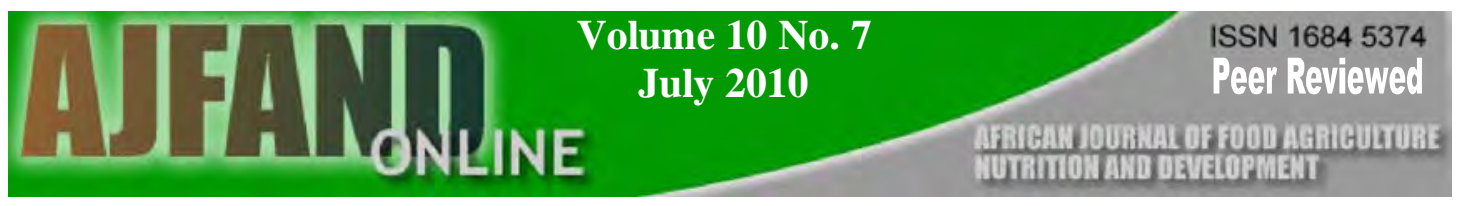

Table 1: Particle size distribution of cola and corn starches

\begin{tabular}{|l|l|l|l|l|}
\hline & \multicolumn{4}{|c|}{ Particles size $(\mu \mathrm{m})$} \\
\hline & $1 \mathrm{~mm}$ & $710 \mu \mathrm{m}$ & $500 \mu \mathrm{m}$ & $<500 \mu \mathrm{m}$ \\
\hline Cola starch (\%) & $8.43 \pm 0.01$ & $15.34 \pm 0.01$ & $25.75 \pm 0.01$ & $50.46 \pm 0.01$ \\
\hline Corn starch (\%) & $1.27 \pm 0.02$ & $10.23 \pm 0.01$ & $20.31 \pm 0.01$ & $68.19 \pm 0.01$ \\
\hline
\end{tabular}


Table2: Some physicochemical and functional properties of cola and corn starches

\begin{tabular}{|c|c|c|}
\hline Parameters & Cola starch & Corn starch \\
\hline $\mathrm{pH}$ & $5.51 \pm 0.10$ & $5.5 \pm 0.10$ \\
\hline Fat $(\%)$ & $0.58 \pm 0.02$ & $0.36 \pm 0.02$ \\
\hline Moisture content $(\%)$ & $10.42 \pm 0.03$ & $8.88 \pm 0.02$ \\
\hline Protein $(\%)$ & $4.60 \pm 0.02$ & $3.27 \pm .0 .01$ \\
\hline Crude fibre & $0.54 \pm 0.00$ & $0.45 \pm 0.02$ \\
\hline Water - soluble ash (\%) & $0.78 \pm 0.00$ & $0.73 \pm 0.01$ \\
\hline Acid insoluble ash (\%) & $0.14 \pm 0.01$ & $0.13 \pm 0.01$ \\
\hline Alkaline soluble ash (\%) & $6.76 \pm 0.01$ & $5.87 \pm 0.01$ \\
\hline Ash content (\%) & $1.06 \pm 0.03$ & $0.85 \pm 0.03$ \\
\hline Amylose: Amylopectin content (\%) & $24 \pm 0.1: 76$ & $27 \pm 0.1: 73$ \\
\hline Iron $(\mathrm{mg} / 100 \mathrm{~g})$ & $0.26 \pm 0.03$ & $0.33 \pm 0.06$ \\
\hline Phosphorous (mg/100g) & $67.43 \pm 0.02$ & $64.51 \pm 0.03$ \\
\hline Potassium (mg/100g) & $4.36 \pm 0.06$ & $3.99 \pm 0.04$ \\
\hline Calcium $(\mathrm{mg} / 100 \mathrm{~g})$ & $9.44 \pm 0.01$ & $10.24 \pm 0.02$ \\
\hline Zinc $(\mathrm{mg} / 100 \mathrm{~g})$ & $0.48 \pm 0.06$ & $0.25 \pm 0.00$ \\
\hline Magnesium (mg/100g) & $3.78 \pm 0.01$ & $2.65 \pm 0.01$ \\
\hline Sodium $(\mathrm{mg} / 100 \mathrm{~g})$ & $1.55 \pm 0.10$ & $1.36 \pm 0.10$ \\
\hline Bulk density $(\mathrm{g} / \mathrm{ml})$ & $0.64 \pm 0.02$ & $0.51 \pm 0.01$ \\
\hline Tapped density $(\mathrm{g} / \mathrm{ml})$ & $0.94 \pm 0.00$ & $0.93 \pm 0.00$ \\
\hline True Density $(\mathrm{g} / \mathrm{ml})$ & $0.94 \pm 0.01$ & $0.93 \pm 0.01$ \\
\hline Foam capacity (\%) & $1.9 \pm 0.10$ & $2.1 \pm 0.10$ \\
\hline Emulsion capacity (1\%) & $5.2 \pm 0.10$ & $46.02 . \pm 0.10$ \\
\hline Water holding capacity & $88.6 \pm 0.20$ & $93.5 \pm 0.10$ \\
\hline Gelatinization Temp $\left({ }^{\circ} \mathrm{C}\right)$ & $74 \pm 0.00$ & $80 . \pm 0.00$ \\
\hline
\end{tabular}




\section{AFALDNEN}

Table 3: Pasting properties of cola and corn starches

\begin{tabular}{|l|l|l|}
\hline Parameters & Cola starch & Corn starch \\
\hline Peak Viscosity (RVU) & $314.42 \pm 0.40$ & $571.90 \pm 0.10$ \\
\hline Trough (RVU) & $135.17 \pm 0.10$ & $342.08 \pm 0.10$ \\
\hline Final viscosity (RVU) & $209.58 \pm 0.10$ & $420.0 .8 \pm 0.10$ \\
\hline Breakdown viscosity (RVU) & $179.25 \pm 0.16$ & $229.3 \pm 0.00$ \\
\hline Set back viscosity (RVU) & $74.43 \pm 0.00$ & $78.00 \pm 0.00$ \\
\hline Peak time (min) & $4.80 \pm 0.00$ & $4.73 \pm 0.00$ \\
\hline Pasting temp $\left({ }^{\circ} \mathrm{C}\right)$ & $74.50 \pm 0.00$ & $80.10 \pm 0.00$ \\
\hline
\end{tabular}

Table 4: DSC thermo grams for cola and corn starches

\begin{tabular}{|c|c|c|}
\hline Parameter & Cola starch & Corn starch \\
\hline Gelatinization temp $\left({ }^{\circ} \mathrm{C}\right)$ & $74.00 \pm 0.10$ & $80.10 \pm 0.00$ \\
\hline Pasting temp $\left({ }^{\circ} \mathrm{C}\right)$ & $74.50 \pm 0.10$ & $80.80 \pm 0.10$ \\
\hline Onset temp To, $\left({ }^{\circ} \mathrm{C}\right)$ & $301.10 \pm 0.10$ & $300.10 \pm 0.10$ \\
\hline Peak temp Tp, $\left({ }^{\circ} \mathrm{C}\right)$ & $321.10 \pm 0.00$ & $316.10 \pm 0.10$ \\
\hline Endset temp Te, $\left({ }^{\circ} \mathrm{C}\right)$ & $340.10 \pm 0.10$ & $330.20 \pm 0.10$ \\
\hline $\mathrm{T}(\mathrm{Te}-\mathrm{To})$ & $39.10+0.00$ & $30.10 \pm 0.00$ \\
\hline
\end{tabular}




\section{REFERENCES}

1. Gebre-M ariam T and PC Schmidt Isolation and physicochemical properties of Endset Starch. Starch/Starke. 1996; 48 (6): 208-214.

2. Ji Y, Pollak LM, Duvick S, Seetharaman K, Dixon PM and PJ White Gelatinization properties of starches from three successive generations of six exotic corn lines grown in two locations. Cereal Chemistry . 2004; 81 (1): 5964.

3. J ayeola CO Preliminary Studies on the use of Kolanuts (Cola nitida) for soft drink production. J. F ood Technol in Africa. 2001; 6 (1): 25 - 26.

4. Beattie GB In: Soft drink flavours: Their history and characteristics. Cola or "Kola" flavor. The flavors industry. 1970: 390-394.

5. Builders PF, Emeji M and OO K unle Some physicochemical properties of Cyperus. J. Pharm. and Allied Sci. 2004; 2 (1): 138-144.

6. AOAC. Official Methods of Analysis of the Association of Official Analytical Chemists $15^{\text {th }}$ ed. Arlington Virginia, 1984.

7. Kunle OO, Yakubu EI, Emeje MO, Sheba S and Y Kunle Extraction, physiochemical and compaction properties of Tacca Starch - a potential pharmaceutical excipient. Starch/Starke. 2003; 55 (7): 319-325.

8. Williams $V R, W u W, T$ sai $H Y$ and $H G$ Bates Varietal differences in amylose content of rice starch. J. Agric \& F ood C hem. 1958; 6: 47-48.

9. Onwuka GI Food Analysis and Instrumentation (Theory and Practice): Naphtali Printers, Lagos. 2005: 133-136.

10. Solsulski FW The Centrifugal method for determining flour absorptivity in hard red spring wheat. Cereal chem. 1962; 39: 244.

11. Carcea $M$ and $R$ Acquistucci Isolation and physicochemical characterization of Fanio (Digitaria exiles stap) starch. starch/starke. 1997; 49 (4): 131-135.

12. Abulade FO Composition and properties of cola nitida and cola acuminate flour in Nigeria. Global J. Pure \& Appl Sci. 2004; 10 (1): 11-16.

13. Shimelis E, M eaza $M$ and $S$ Rakshit Physiochemical properties, pasting behavior and functional characteristics of flours and starches from improved bean (Phaseolus vulgaris L.) varieties grown in East Africa. Agric Eng Int: The CIGR EJ ournal. 2006; FP 05015 Vol. VIII. 
14. Ihegwuagu $\mathrm{NE}, \mathrm{O}$ mojola $\mathrm{MO}$, Emeje $\mathrm{MO}$ and $\mathrm{OO} \mathrm{K}$ unle Isolation and evaluation of some physicochemical properties of Parkia biglobosa starch. J. Pure and Appl chem. 2009; 81:97-104.

15. Yuan $Y$, Zhang $L$, Dai $Y$ and J $Y u$ Physicochemical properties of starch obtained from Dioscorea nipponica Makino comparison with other tuber starches. J. Food Eng. 2007; 82 (4): 436-442.

16. Galliard $\mathrm{T}$ and $\mathrm{P}$ Bowler Morphology and Composition of starch. In: Galliard, T. (Ed). John Wiley, New York, 1987: 55-77.

17. W atson SA Starch, Chemistry and Technology. In: $2^{\text {nd }}$ ed. Academic Press, New York, 1984: 461-462.

18. L oss PJ , Hood LF and HD Graham Isolation and Characterization of Starch from Breadfruit. Cereal Chem. 1981; 58(4): 282-286.

19. Tester RF and WR M orrison Swelling and gelatinization of cereal starches. Effect of amylopectin, amylose and lipids. Cereal Chem. 1990; 67: 551-557.

20. Abera S and SK Rakshit Comparison of physiochemical and functional properties of cassava starch extracted from fresh root and dry chips. Starch/Starke, 2003; 55(7): 287-296. 
PERCENT SOLUBILITY OF COLA AND CORN STARCHES

\begin{tabular}{|l|l|l|}
\hline Temperature & Cola starch & Corn starch \\
\hline 5 & $2.08 \pm 0.01$ & $3.35 \pm 0.02$ \\
\hline 10 & $2.23 \pm 0.02$ & $3.45 \pm 0.01$ \\
\hline 15 & $2.45 \pm 0.02$ & $3.68 \pm 0.00$ \\
\hline 20 & $2.75 \pm 0.02$ & $4.11 \pm 0.00$ \\
\hline 25 & $3.25 \pm 0.01$ & $4.25 \pm 0.02$ \\
\hline 30 & $3.55 \pm 0.00$ & $4.55 \pm 0.02$ \\
\hline 35 & $3.65 \pm 0.00$ & $4.70 \pm 0.01$ \\
\hline 40 & $4.25 \pm 0.02$ & $4.76 \pm 0.02$ \\
\hline 45 & $4.65 \pm 0.01$ & $5.05 \pm 0.02$ \\
\hline 50 & $4.85 \pm 0.01$ & $5.65 \pm 0.00$ \\
\hline 60 & $5.05 \pm 0.01$ & $5.95 \pm 0.00$ \\
\hline 70 & $5.95 \pm 0.02$ & $6.75 \pm 0.01$ \\
\hline 80 & $6.62 \pm 0.00$ & $7.58 \pm 0.01$ \\
\hline 90 & $7.48 \pm 0.00$ & $9.33 \pm 0.01$ \\
\hline 100 & $8.22 \pm 0.00$ & $9.40 \pm 0.02$ \\
\hline
\end{tabular}

PERCENT SWELLING POWER OF COLA AND CORN STARCHES

\begin{tabular}{|l|l|l|}
\hline Temperature & Cola starch & Corn starch \\
\hline 5 & $4.35 \pm 0.02$ & $4.67 \pm 0.01$ \\
\hline 10 & $4.66 \pm 0.01$ & $4.78 \pm 0.02$ \\
\hline 15 & $4.75 \pm 0.01$ & $4.95 \pm 0.00$ \\
\hline 20 & $5.05 \pm 0.00$ & $5.73 \pm 0.01$ \\
\hline 25 & $5.35 \pm 0.01$ & $5.95 \pm 0.01$ \\
\hline 30 & $5.60 \pm 0.02$ & $6.08 \pm 0.02$ \\
\hline 35 & $6.15 \pm 0.01$ & $6.28 \pm 0.02$ \\
\hline 40 & $6.25 \pm 0.01$ & $6.75 \pm 0.01$ \\
\hline 45 & $6.34 \pm 0.01$ & $6.84 \pm 0.00$ \\
\hline 50 & $6.50 \pm 0.02$ & $7.05 \pm 0.01$ \\
\hline 60 & $6.74 \pm 0.02$ & $7.25 \pm 0.02$ \\
\hline 70 & $7.05 \pm 0.01$ & $7.35 \pm 0.02$ \\
\hline 80 & $7.25 \pm 0.01$ & $8.74 \pm 0.01$ \\
\hline 90 & $8.85 \pm 0.00$ & $10.22 \pm 0.01$ \\
\hline 100 & $9.33 \pm 0.01$ & $10.58 \pm 0.01$ \\
\hline
\end{tabular}

